\title{
Some structural characteristics of mixed natural forest stand at a 10- year period in the Hyrcanian Region: Case study of Shourab Forest, Mazandaran Province, Iran
}

\author{
MOJTABA AMIRI \\ Department of Forestry, Faculty of Desert Studies, Semnan University. Semnan, Iran. Tel: +98-916-9596900, email: mojtabaamiri@semnan.ac.ir.
}

Manuscript received: 8 December 2018. Revision accepted: 9 March 2019.

\begin{abstract}
Amiri M. 2019. Some structural characteristics of mixed natural forest stand at a 10-year period in the Hyrcanian Region: Case study of Shourab Forest, Mazandaran Province, Iran. . Biodiversitas 20: 950-955. This research was carried out in Shourab Forest in the Hyrcanian region, Northern Iran over a 10-year period (1996-2005) and data were analyzed based on systematic random sampling with permanent sample plots; 0.1 ha. The results revealed that $n . \mathrm{ha}^{-1}$ and $\mathrm{v} \cdot \mathrm{ha}^{-1}$ in study area increased from 126.3 and 245.2 in 1966 to 202.8 and 313.1 in 2006, respectively. The analysis of tree frequency in diameter classes at the first and the end of the period indicated un-even aged regular stands. The highest increase of number of trees was observed in 15,20 and $25 \mathrm{~cm}$ diameter classes, While the maximum change in volume per hectare, is related to the diameter classes $30,65,70$ and $100 \mathrm{~cm}$. The regeneration values in most of the vegetation stages (except; $0-2.5 \mathrm{~cm}$ ) increased after a 10 years harvesting period. Development stages of this regeneration were seedling (53.4-53.3\%), sapling (37.3-33.5\%), thicket (6.8-10.4\%) and small pole (2.5-2.8\%), in 1996 and 2006, respectively. These conditions show that the selection method has been successful in our study area. The change in the utilization method of shelter-wood system to selection cutting method had been a positive impact on the quantitative forest condition after a 10-year period. In general, it can conclude that structural characteristics of mixed beech-hornbeam stands such as live trees dimension including tree height and diameter, number and volume of trees per hectare are different during the time. And eventually, the manipulation in the stands should be well timed and planned based on quantified structural properties of stands.
\end{abstract}

Keywords: Diameter classes, Hyrcanian forests, quantitative characteristics, vegetation stages

\section{INTRODUCTION}

Stand structure and composition are key attributes of a forest ecosystem (Crow et al. 2002; Chen and Popadiouk 2002) that effect on function and its relationship components (Amiri et al. 2013). On the other hand, changes in stand structure may occur naturally and from human intervention (e.g., utilization, application of silvicultural treatments, etc.) (Amiri et al. 2013). Forest structure changes are driven by various stand-initiating disturbances, partial disturbances, and autogenic processes (Delong and Kessler 2000). As a stand develops, many interactions, or processes, occur among trees, between trees and the environment with different processes becoming more dominant as stands change (Gadow 2005). Understanding stand structure and development are useful in prediction of the effects of interventions for the management objectives. Management objectives may include habitat improvement, restoration, and reconstruction of ecosystem functions or growth of trees as production wood (Sharma et al. 2003). Today, most countries assess their forest resources every few years, and the results are provided for the forest managers, experts, and researchers interested in this field. In Iran, every ten years and regularly, the forestry projects are evaluated under the revision plan which in this case 6 periods of 10 years can be noted which have been carried out 1960 to 2010 years in Hyrcanian forest (Amiri et al. 2016).
Monitoring and evaluating the results of national inventories and implementation of short-term and longterm forestry projects and also detecting the changes in the structure and composition of forests under the management and monitoring the results with respect to the objectives of plans is one of the main resource management pillars (Aghili 2009; Amiri et al. 2016). The objective for designing and management of forest is decision-making and applying it to change the structure and composition of forests with respect to the determined objectives and pushing forest to the more desirable situation which is carried out through administrative instructions and training by cutting trees in different ways. The results of the monitoring and control them in addition to illustrates the amount of changes in the performance of projects, it can also be a useful guide in making correct decisions on the continuation of the design and enforcing them. Evaluation of quantitative and qualitative changes, developments, and the results of the effect of natural factors and human interference during the statistical periods specified in nature highly influences the management method and silvicultural operations of forests in each region (Etemad 1994). Analysis of data obtained from recognized statistical courses can be used to review management systems, exploitation of natural resources, and short-term and longterm planning fundamental in directing the programs and policies of each country's natural resources in connection with the restoration, optimum and effective development 
and using of the forest (Amiri et al. 2016). Although the history and implementation of forestry in some European countries are more than three centuries, In Iran the history of forestry projects is less than 80 years. Since the implementation of the first forestry project in Iran (1960) so far, every 10 years changes and developments can be observed in the way of development and implementation of forestry plans in accordance with scientific principles in the Hyrcanian forest, but the experiences obtained from the implementation of these projects has not been edited so far to be a useful tool for forest managers in the Hyrcanian region, north of Iran (Etemad et al. 2013).

In evaluating the conditions of forest management plans in the Hyrcanian region, many studies have been conducted all of which have emphasized the effects of implementing forestry projects on the change of quantitative and qualitative characteristics in the stand structure of forest including the studies (Asadi-Otouei 2000; Aghili 2009; Hassanzad-Navroodi et al. 2009; Amiri et al. 2013 and 2016; Etemad et al. 2013; Sasanifar et al. 2015; JavanmiriPour et al. 2017; Rezaei-Sangdehi et al. 2017). Changes in forests status in district one of Shast-Kalate forest of Gorgan has been assessed in aspects of forest structure and composition of the series and the masses in a 30-years period. The results showed that the characteristics of density, basal and volume per hectare during the study period showed no significant difference (Aghili 2009). The results of Hassanzad-Navroodi et al. (2009) also showed that there is no significant difference between the mean volume and basal area per hectare at the beginning and end of a 10-year period (1995-2005) but the volume and basal area per hectare have been decreased after 10 years of implementation. Study of Etemad et al. (2013) in Kheiyroud of Noshahr (north of Iran) after implementing a 10-year period (1984-1994) of forestry plan revealed that curves of tree height have been increased and tree volume and quality of the first degree has also been increased. The percentage of volume per hectare of species has been increased than border of planning and Hornbeam and oak species it has been closer to the ideal goals. In another study conducted in Chelir district of Kheiyroud, changes in quantitative characteristics of a natural stand were assessed in 8 years. The results showed that the average of height dominant of the mass and relative height ratio has been decreased while Slenderness coefficient of the stand has been reduced. Also, in a study in the Kheiyroud forest using data collected in 1970 to 2003 years, changes of quantitative characteristics in two areas of Faguetum orientalis and Fagus orientalis-Carpinetum community were compared and the results showed that in Hyrcanianbeech community, no significant changes had been achieved during different periods in terms of quantitative characteristics, while these changes were significant in the beech-hornbeam stand (Sasanifar et al. 2015).

Additionally, the changes in stand structure characteristics of forests of Golestan province in an 11-year period (1996 to 2007) was evaluated. The results of this study showed that although quantitative characteristics of number and volume per hectare have decreased during the period, the conservation status of forest has increased in some areas (Amiri et al. 2016). The aim of this study was to evaluate changes in the structural characteristics of forest stands at the beginning and end of a 10-year period (19962006) in the district of Shourab Forest of Mazandaran province in the Hyrcanian region, north of Iran.

\section{MATERIALS AND METHODS}

\section{Study area}

District two of Shourab forest management plan with an area of 2620 hectares is located in jurisdiction area of Natural Resources of Noushahr and is also located in 45 Golband watershed catchments according to the division of the country in 1975. The site of forests in this area is located in the middle and as a mountainous. Forests of district 2 are located between the longitudes of $36^{\circ} 27^{\prime} 36^{\prime \prime}$ $36^{\circ} 32^{\prime} 41^{\prime \prime} \mathrm{N}, 51^{\circ} 30^{\prime} 28^{\prime \prime}-51^{\circ} 37^{\prime} 53^{\prime \prime} \mathrm{E}$. The elevation of the study area ranged from 460 to $1645 \mathrm{~m}$ asl. Selected forest communities occupy plateaus or moderately inclined slopes (less than 50\%), which are dominated by moderately acidic to alkaline brown forest soils. The average rainfall in the forests of the district 2 is $709 \mathrm{~mm}$. The minimum and the maximum amount of rainfall is in August (7.24) and October $(131 \mathrm{~mm})$, respectively. Also according to the classification method of cold and humid climates, it is a cold and wet climate $(\mathrm{Q}=61.7)$. The soil texture is mostly clay loam to sandy clay (DNRWM 2010). Forest stands are dominated by broad-leaved species such as Fagus orientalis Lipsky, Carpinus betulus L., Parrotia persica C.A.Mey. Alnus subcordata, Quercus castaneifolia C.A.Mey, Acer velutinum Boiss.), Acer cappadocicum Aureum, Diospyros lotus L., Tilia platyphyllos Scop., Cerasus avium (L.) Moench, Sorbus torminalis (SaghebTalebi et al., 2014), and a single selection system is performed in this site.

\section{Field measurement and data analysis}

In this study, changes in the structural characteristics of forest stand district 2 of Shourab forest management plan includes a D.B.H $(<1.30 \mathrm{~m})$, total height, number, basal area, and volume per hectare after the implementation of a 10-year period (1996-2006) was studied. The sampling network size was $150 \times 200 \mathrm{~m}$, and inventory intensity was $3.3 \%$ (Zobeiri 2008). Also, the distances between sampling strips were $200 \mathrm{~m}$, and the distances between circular plots (376 plots) on strips were $150 \mathrm{~m}$ according to elevation changes of forest type (Mohammadi et al. 2013). the area of plots was $1000 \mathrm{~m} 2$ (Zobeiri 2008). In total district, data of a total of 376 plots were used to compare the quantitative changes of forest stand structure. The volume of invented trees was calculated using local tariff of forest management plan and then the average of the volume and density to the total stand of any species was calculated.

Moreover, to demonstrate better analysis of changes in number and volume and per hectare before and after the study period, due to the Technical Office of Forests and Rangelands Organization guidelines, for the preparation of forest management plan northern of Iran, trees were classified in four diameter classes of; small width 10 to 30 
$\mathrm{cm}$, medium width 35 to $50 \mathrm{~cm}$ and large, 55 to $80 \mathrm{~cm}$ and very large width class including trees more than $85 \mathrm{~cm}$ and were organized. To assess the quantitative characteristics of tree regeneration in the study area, information of microplots obtained during the first and end period (1996 and 2006) were used. Then this data was classified in onecategory of fewer than $0.5 \mathrm{~m}$ height (seedling) and three diameter classes including; $0.5-2.5$ (sapling), 2.5-7.5 (thicket) and 7.5-12.5cm, small pole (Amiri et al. 2009 b). For comparison of the average number and volume per hectare of the stands at the beginning and end of the inventory period, independent t-test was used. Drawing all the charts was performed in Excel software and statistical data analysis software SPSS, ver.19.

\section{RESULTS AND DISCUSSION}

\section{Results}

Forest was dominated by four species Oriental beech (Fagus orientalis Lipsky), Common hornbeam (Carpinus betulus L), oak, (Quercus castaneifolia C.A.Mey) and Caucasian alder (Alnus subcordata) that accounted for $90 \%$ of the total density and volume in both 1996 and 2006. The average number and volume per hectare of all tree species with $\mathrm{DBH}<12.5 \mathrm{~cm}$ at the beginning and the end of the period are shown in tables 1 and 2. Table one showed that during 10 years, the total density of stands changed from $132.3 \mathrm{n} \cdot \mathrm{ha}^{-1}$ to $202.8 \mathrm{n} \cdot \mathrm{ha}^{-1}$. The frequency of per hectare beech, other industrial species and firewood species increased at the end of the period (2006) compared to the first period (1996). While the number of hectares of hornbeam, oak, and alder decreased at the end of the period (Table 1). Beech accounted for $78.4 \mathrm{n} \mathrm{ha}^{-1}$ in 1996, while this rate raised to $111.4 \mathrm{n} \cdot \mathrm{ha}^{-1}$ in 2006 . The proportion of hornbeam in the year 1996 (27\%) was greater than in 2006 (26.92\%). The average stand volume increased from 245.7 (1996) to $313.1 \mathrm{~m}^{3} \cdot \mathrm{ha}^{-1}$ (2006). Thus, during the ten years of implementation of the forest management plan, the stand volume has increased by $67.4 \mathrm{~m}^{3}$. Also, the results showed that beech and hornbeam alone accounted for about $80 \%$ of the stand volume both in 1966 and 2006. The volume of oak and alder increased from 13.2 and 12.3 (1996) to 22.7 and 22.2 (2006), respectively (Table 2).

The analysis of tree frequency in diameter classes indicated multi-aged stands. Thus, the dbh distribution of trees exhibited reverse $\mathrm{J}$ or L-shape distribution, both in 1996 and 2006. Figure 1 shows distribution in diameter classes of two series Shourab forest both in 1996 and 2006. As observed, the highest variation in number per hectare has occurred in thin diameter classes $(15-25 \mathrm{~cm})$. But as the diameter of the trees increases, this difference gradually decreases in the initial period (1996) with the end of the period (2006). So that in diameter classes of 100 to $110 \mathrm{~cm}$, tree diameter distribution in both periods coincides. But in the D.B.H >115 (in 2006), tree diameter distribution is higher than in 1996.
Table 1. Comparison of number per hectare of trees based on species at Shourab Forest, Mazandaran, Iran from 1996 to 2006

\begin{tabular}{lcccc}
\hline \multirow{1}{*}{ Species } & \multicolumn{2}{c}{$\mathbf{1 9 9 6}$} & \multicolumn{2}{c}{$\mathbf{2 0 0 6}$} \\
\cline { 2 - 5 } & $\begin{array}{c}\text { Density } \\
\left(\mathbf{n ~ h a}^{-1}\right)\end{array}$ & $\%$ & $\begin{array}{c}\text { Density }^{\left(\text {(n ha }^{-1}\right)} \\
\text { \% }\end{array}$ \\
\hline Oriental beech & 78.4 & 59.25 & 111.4 & 57.77 \\
Common hornbeam & 35.7 & 27 & 54.6 & 26.92 \\
Oak & 3.1 & 2.35 & 6.7 & 2.30 \\
Caucasian alder $_{\text {Other species industrial }}^{*}$ & 7.4 & 5.6 & 13.4 & 4.60 \\
Firewood Species $^{* * *}$ & 6.5 & 5 & 10.9 & 6.37 \\
Total & 1.2 & 0.90 & 5.8 & 2.16 \\
\hline Nol & 132.3 & 100 & 202.8 & 100 \\
\hline
\end{tabular}

Note: *Maple, Wyche elm, Lime, Wild service tree, ${ }^{* *}$ Ironwood, Date plum

Table 2. Comparison of volume per hectare of trees based on species at Shourab Forest, Mazandaran, Iran from 1996 to 2006

\begin{tabular}{|c|c|c|c|c|}
\hline \multirow[b]{2}{*}{ Species } & \multicolumn{2}{|c|}{1996} & \multicolumn{2}{|c|}{2006} \\
\hline & $\begin{array}{l}\text { Volume } \\
\left(\mathbf{m}^{3} \mathbf{h a}^{-1)}\right.\end{array}$ & $\%$ & $\begin{array}{l}\text { Volume } \\
\left(\mathbf{m}^{3} \mathbf{h a}^{-1)}\right.\end{array}$ & $\%$ \\
\hline Oriental beech & 158.2 & 64.38 & 191.8 & 61.23 \\
\hline Common hornbeam & 42.5 & 17.29 & 50.6 & 16.15 \\
\hline Oak & 13.2 & 5.37 & 22.7 & 7.24 \\
\hline Caucasian alder & 12.3 & 5.00 & 22.2 & 7.08 \\
\hline Other species industrial* & 17.2 & 7.00 & 21.6 & 6.9 \\
\hline Firewood species ${ }^{* *}$ & 2.3 & 0.93 & 4.2 & 1.35 \\
\hline Total & 245.7 & 100 & 313.1 & 100 \\
\hline
\end{tabular}

Note: *Maple, Wyche elm, Lime, Wild service tree, ${ }^{* *}$ Ironwood, Date plum

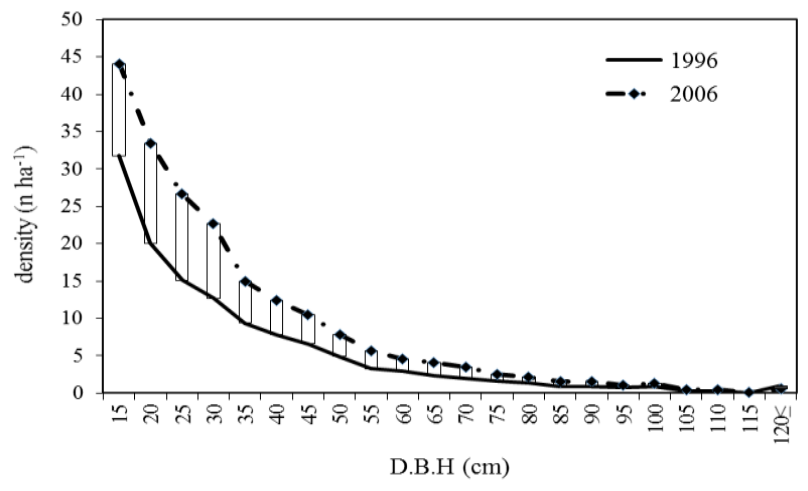

Figure 1. D.B.H distribution for common species of mixed stand at Shourab Forest, Iran

As mentioned above, during 10 years, the total volume of stands changed from $245.7 \mathrm{~m}^{3} \cdot \mathrm{ha}^{-1}$ to $313.1 \mathrm{~m}^{3} \cdot \mathrm{ha}^{-1}$. As for the volume distribution per hectare of diameter classes, the variations are in a sinusoidal shape such that compared to the beginning of the sampling period, at the end of the given period, a considerable increase in volume per hectare is observed in diameter classes of $30,35,65,70,75$ and $100 \mathrm{~cm}$. However, in other diameter classes, the volume per hectare of trees has increased at the end of period (in 2006) (Figure 2). 


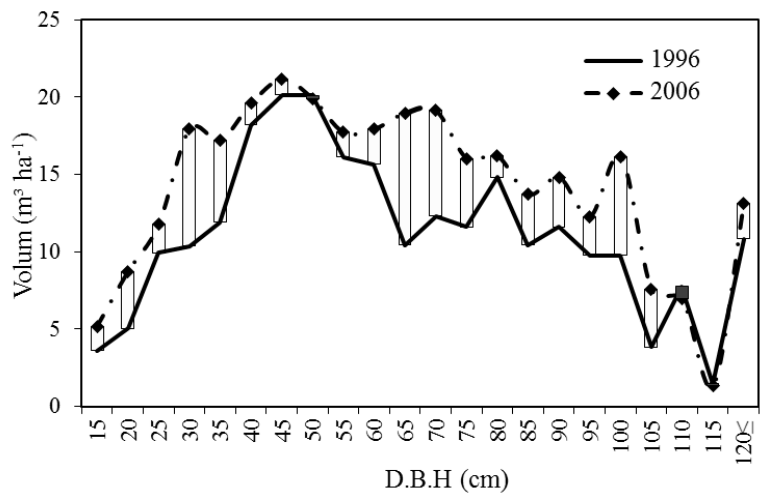

Figure 2. Trees volume distribution in diameter classes for common species of mixed natural stands at Shourab Forest, Hyrcanian region

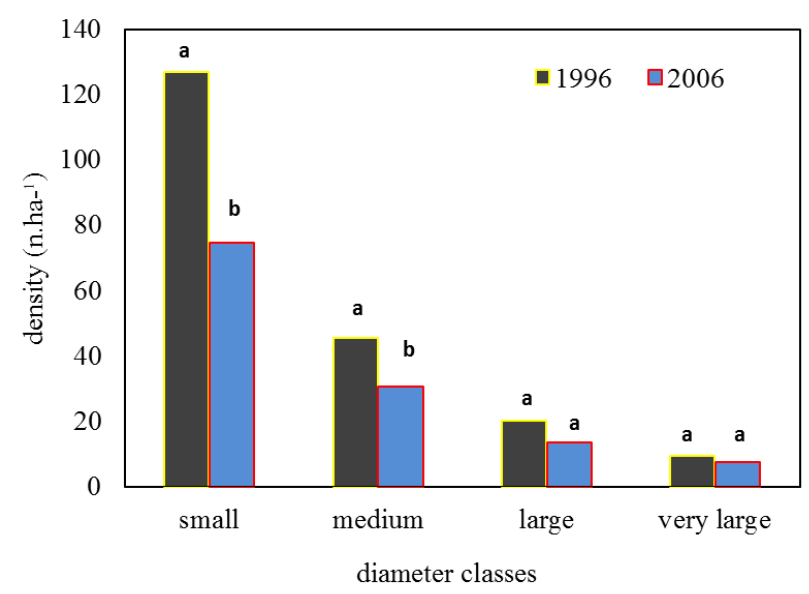

Figure 3. Frequency distribution of trees in diameter classes at beginning (1996) and end (2006) sampling period in the Shourab forest, Hyrcanian region

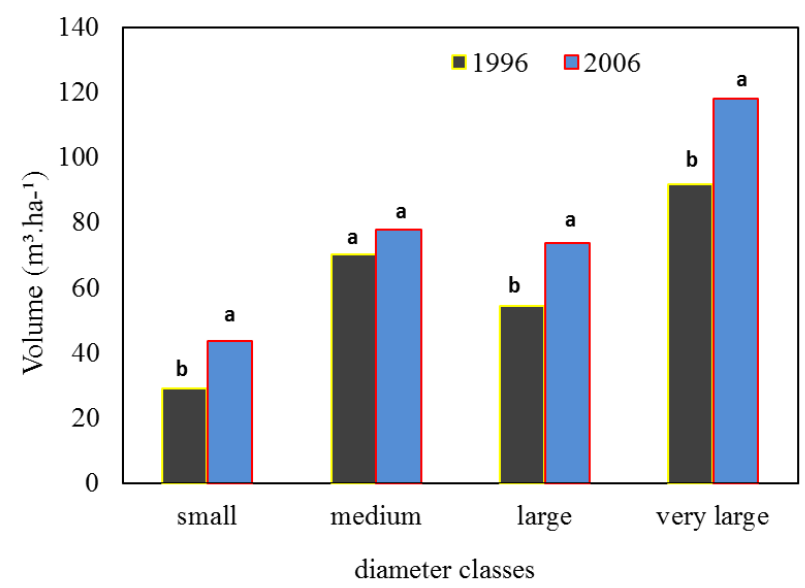

Figure 4. Stock growth distribution of trees in diameter classes at beginning (1996) and end (2006) sampling period in the Shourab forest, Hyrcanian region

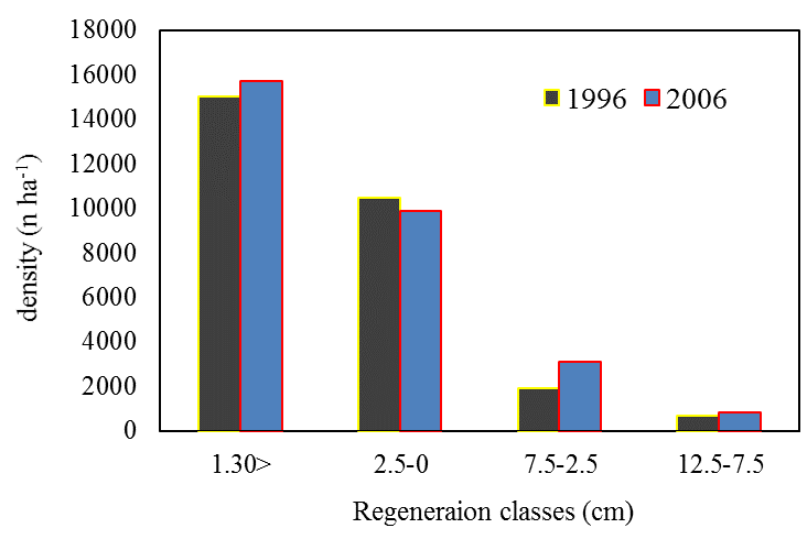

Figure 5. Structural characteristics of regeneration stages in the Shourab Forest, Hyrcanian region

The highest number of trees was found in the small diameter class $(\leq 30 \mathrm{~cm})$ over the 10 years, whereas the lowest number of trees was found in the largest diameter class, both in 1996 and 2006 (Figure 3). Mean differences in density in all diameter classes was positive during the 10-year period (75.17 n.ha $\left.{ }^{-1}\right)$. While the largest mean differences of Stock growth was in the largest diameter class, having value of $+67.4 \mathrm{~m}^{3} \cdot \mathrm{h}^{-1}$ in comparison with 1996. Also, It is obvious that the highest volume of trees was distributed in dbh classes $>75 \mathrm{~cm}$, while low numbers of trees were distributed in small diameter classes (Figure 4). There were significant differences $(P=<0.05$ and $\mathrm{P}=<0.001$ ) between all species density and volume before and after selection cutting (Table 3 ).

Data regeneration of species was categorized in four vegetation stages of seedling $(<0.5 \mathrm{~m}$ height $)$, sapling $(0$ $2.5 \mathrm{~cm})$, thicket $(2.5-7.5 \mathrm{~cm})$, and small pole $(7.5-12.5 \mathrm{~cm})$. The regeneration values in most of the vegetation stages (except; $0-2.5 \mathrm{~cm}$ ) increased after a 10 year harvesting period. Development stages of this regeneration were seedling (53.4\%), sapling (37.3-33.5\%), thicket (6.8$10.4 \%$ ) and small pole) 2.4-2.8\%), in 1996 and 2006, respectively. As observed in Figure 6, the highest frequency of species regeneration is in seedling vegetation stage, both in 1996 and 2006.

\section{Discussion}

Forest ecosystems are one of the most vital natural blessings that have served human beings since very early centuries. Having been quantitatively and qualitatively degraded due to population growth, extension of civilizations, conversion of forest to agricultural land, development of industries and cities, grazing, and fire, forests are also being increasingly exposed to the recent generation's interventions which highly threaten the existence of natural forests in near future (Amiri et al. 2016). This study in the Shourab Forest, Hyrcanian region revealed the dynamics of structural characteristics in a mixed natural board-leaved stands forest at 10-year period.

Significant changes for individual species were evident between the 1996 and 2006 surveys. Overall, the 
frequencies of woody species in this study increased steadily in frequency percentages over time. Comparative sampling analysis of the results derived from the two overall inventories from Shourab forests revealed that in terms of number and volume per hectare, increased by 76.5 nha $^{-1}$ and $67.4 \mathrm{~m}^{3} \mathrm{ha}^{-1}$, respectively. During the sampling period, the mentioned gain was more considerable in species such as beech, hornbeam, and oak compared to other species. Firewood and other industrial species showed a minimum increase in frequency between the 1996 and 2006 surveys. While the maximum increase in the number and volume per hectare belonged to oak and alder (Table 1). Information about the composition of tree species in forest ecosystems helps in prediction of the type and abundance of the species, the importance of species for silvicultural operation, and the future status of stands. As observed, the composition of tree species in Shourab forest management plan has undergone significant changes through the given sampling period such that compared to the beginning of the sampling period (1996), the frequency of species increased at the end of the period (2006). Also, despite the increase in the number and volume per hectare at the end of the period compared to the first period, Table 1 shows the change in the percentage of these two variables in the diameter classes was not so significant, which can cause a low change in the stand structure over a period of 10 years. One of the reasons for increasing the number and volume per hectare of stand at the end of period has been the decline in harvesting of forests in recent years. The change in the utilization method of shelterwood system to selective logging system, as well as the rest of the forest and the importance of the Hyrcanian forests, have been a factor in reducing the utilization of the forests of this region. In the study of Etemad et al. (2013) in Namkhane district Kheyrud Forest, except for the number per hectare, other characteristics of the stand structure at the end of the period have increased. In Farim forest, Mazandaran province in the 10-year period was found that the average number, volume, basal area and Lorey's mean height of trees increased (Sasanifar et al. 2015).

Also, Amiri et al. (2016) in Golestan forests and Javanmiry-Pour et al. (2017) in Gorazbon district, Kheyrud forest in the Hyrcanian region reported that some of stand structure characteristics at the end of inventory compared to the first inventory increased. Whereas in previous studies the number and volume per hectare of most species, especially industrial species, decreased after the end of the period. One of the reasons behind the reduction of frequency in these species lies in the excessive utilization of the forest management plans implemented for the last 50 years in Hyrcanian region. Suh and Lee (1998), Esteghamat (2000), Webb and Sah (2003), Angres et al. (2005), Patto (2007) and Amiri et al. (2009a) reported that compared to natural stands, combination of the dominant tree species in utilized stands exhibited some changes such that in most cases, the endemic and dominant species were replaced by the undesirable forest floor herbal species.

The analysis of tree frequency in diameter classes indicated multi-aged stands. Thus, the dbh distribution of trees exhibited reverse $\mathbf{J}$ or L-shape distribution, both in
1996 and 2006 (Figure 1). This is one of the features of uneven-aged forests of Hyrcanian forests that have different diameter sizes. DBH differentiation also caused to the slightly heterogeneous in diameter distribution within stands. However, the tree diameter distribution within size classes showed the same pattern in comparison with aging phase in the north of Iran. Sefidi et al. (2015) report reverse $\mathrm{J}$ shape curve in mixed beech stands. The same results reported in the oriental beech mixed stands in the north of Iran (Marvie Mohadjer et al. 2009; Hassani and Amani 2009; Sagheb-Talebi et al. 2014; Amiri et al. 2013 and 2016) and in European beech forest (Leibundgut 1993; Cancino and Gadow 2002; Mayer et al. 2004). Findings of Hasani and Amani (2009) in the Sangdeh forest in the Caspian region showed that distribution of stem number per diameter classes was homogeneous (Bell-shaped) with a semi even-aged structure. While, Sagheb-Talebi and Schutz (2002) found that the natural beech stands in the Caspian region illustrate an irregular, heterogeneous and uneven-aged structure at the minimum area of one ha. After end of period, the highest stock growth of trees was distributed in dbh classes of $30,35,65,70$ and $100 \mathrm{~cm}$, respectively, whereas during 10 years the total volume of the stands changed from $245.7 \mathrm{~m}^{3} \mathrm{ha}^{-1}$ to $313.1 \mathrm{~m}^{3} \mathrm{ha}^{-1}$. These conditions show that the selection method has been successful in our study area. The results of this study showed that the small diameter classes had the highest increase in the number of hectares at the end of the period (2006). Whereas, very large diameter classes did not have much change over the first period. Amiri et al. (2009 a) indicated that in the studied stands of Loveh oak forest (Golestan Province), the density and canopy of trees have had major role in the formation and thus future status of a forest. Density is, on the one hand, an influential factor in the assessment and prediction of forest status (Patto 2007), and on the other, an effective aid for the overall assessment of the site's natural status, and canopy structure (Amiri et al. 2016). In terms of condition of forest regeneration, the frequency of existing seedlings and saplings in study area is varied. As the results indicate in end of period, the frequency of seedlings and saplings $0.5 \mathrm{~m}$, shows the highest rate of regeneration amongst the other vegetation stages. The regeneration values in most classes were increased after a 10-year harvesting period, excepted regeneration class $0-2.5 \mathrm{~cm}$. Development stages of this regeneration were 50 seedling, $42 \%$ sapling, and $3 \%$ thicket, both in 1996 and 2006.

Nowadays, in most of the managed mixed broad-leaved species stands in the Hyrcanian forests, north of Iran, there are efforts to restore structure of the stands toward the natural and intact structure. Therefore, there is a need for quantifying stands in the natural state. Repeated measures and observations at beginning and end of a period 10 years old in plot no. 367 indicated that the studied forest represented a natural ecosystem with density and timber volume typically evenly stratified between diameter classes, with an uneven-aged structure. Changes that took place in the studied forest since 1996 to 2006 were influenced by human activities, but we have hopefully, thanks to its position in the Shourab Forest. Because of the 
number and volume per hectare increased at the end of the period of 10 years, and this natural course of the forest development will be maintained in future. Consistent with this trend is the observation that the establishment and regeneration of all species seedlings and saplings has greatly increased with selection cutting after 10 years. Also, the study showed different stand elements of natural mixed beech-hornbeam forests and demonstrated that they exhibit considerable composition and structural diversity. We can conclude that structural characteristics of mixed beech-hornbeam stands such as live trees dimension including tree height and diameter, number and volume of trees per hectare are different during the time. And eventually, the manipulation in the stands should be well timed and planned based on quantified structural properties of stands.

\section{ACKNOWLEDGEMENTS}

The author gratefully acknowledges for assistance provided by Semnan University, Iran, especially the Department of Forestry, Iran and Also, Latif Safarpour for data collection.

\section{REFERENCES}

Aghili SR. 2009. Evaluation of quantitative and qualitative forest stands changes in the Shast-Kalateh management Plan. [Thesis]. Gorgan University of Agricultural Sciences and Natural Resources, Gorgan, Iran. [Persian]

Amiri M, Dargahi D, Habashi H, Azadfar D. 2009a. Comparison structure of the natural and managed Oak (Quercus castaneifolia) stand (shelterwood system) in Forest of Loveh, Gorgan. J Agri Sci Natur Res 15 (6): 44-53. [Persian].

Amiri M, Dargahi D, Habashi H, Azadfar D, Solaymani N. 2009b. Comparison of regeneration density and species diversity in managed and natural stands of Loveh Oak Forest. J Agri Sci Natur Res 15 (6): 54-64. [Persian].

Amiri M, Naghdi R, Moghadasi D. 2016. Assessment of Quantitative and Qualitative Characteristics of Golestan Province Forests in an 11Year Period (Iran). Intl J Environ Resour Res 4 (2): 195-212.

Amiri M, Ramani R, Sagheb-Talebi Kh, Habashi H. 2013. Dynamics of structural characteristics of a natural unlogged oriental beech (Fagus orientalis Lipsky) stand in Shast Kalate Forest, North of Iran. Intl J Environ Resour Res 1 (2): 107-129.

Angress VA, Messier Ch, Beaaudet M, Leduc A. Comparing composition and structure in old-growth forest. For Ecol Manag 217: 275-293.

DNRWM. 2010. Forestry Plan Management. Department of Natura Resources and Watershed Management in Mazandaran Province, Mazandaran, Iran [Persian].

Asadi Atoei E. 2000. Investigation and evaluation of implementation of Shelterwood system in Makarud forestry plan. Proceedings of National Conference of Northern Forests and Sustainable Development, Ramsar. 229-269.

Cancino J, Gadow KV. 2002. Stem number guide curves for un-even aged forests, development and limitations. In: Gadow KV, Nagel J, Saborowski J (eds.). Continuous Cover Forestry. Kluwer Academic, Dordrecht.

Chen HYH, Popadiouk RV. Dynamics of North American boreal mixed woods. Environ Rev 10: 137-166.

Crow TR, Buckley DS, Nauertz EA, Zasada JC. 2002. Effects of management on the composition and structure of northern hardwood forests in Upper Michigan. Forest Sci 48: 129-145.

Darvish Sefat AA. 1985. An investigation on quality and quantity changes due to implementation of Forest Management Plan in the Patom District, Kheyrud Forest. [Thesis].Natural Resources Faculty,
University of Tehran, Tehran.

Delong SC, Kessler WB. 2005. Ecological characteristics of mature forest remnants left by wildfire. For Ecol Manag 131: 93-106.

Denslow, JS. 1980. Gap partitioning among tropical rainforest trees. Biotropica 12: 47-55.

Esteghamat M. 2000. The effect stands structure on the regeneration in the natural and managed stands (shelterwood system) in the Ziarat forest (Gorgan). [Thesis]. Gorgan University of Agriculture Sciences and Natural Resources, Gorgan, Iran. [Persian].

Etemad V. 1994. Investigation of changes stand volume after 10 years of implementation in Namkhane of KHeyrud forests. [Thesis]. Tehran University, Tehran, Iran. [Persian]

Etemad V, Namiranian M, Zobeiri A, Majnounian B, Moradi Gh. 2013. Qualitative and Quantitative Variation of Forest Stands after one Period of Forest Management Plan (Case study: Namkhane District of Kheyrud Forest). J For Wood Prod 66 (3): 243-256. [Persian]

Gadow VK. 2005. Forsteinrichtung: Analyse und Entwurf der Waldentwicklung. Universitatsverlag Gottingen, Gottingen. [Germany]

Hasanzad Navrodi I, Seyyedi N, Seifolahian R. 2009. Evaluation of quantitative forests stands changes during a period of forest management plan (case study: Jabe sara district-Guilan). Iranian J Forest 1 (4): 301-311. [Persian]

Hassani M, Amani M. 2009. Investigation on some qualitative and quantitative characteristics of oriental beech in the optimal phase (Case study: Sangdeh, Caspian forests of Iran). Iranian J Forest and Poplar Res 17 (1): 134-148. [Persian]

Javanmiri Pour M, Marvie Mohadjer MR, Zobeiri M, Etemad V, Jourgholami M. 2017. Quantitative changes of forest stand structure through full calipering method (Case Study: Gorazbon district, Kheiyrud Forest, Noshahr). Iranian J Forest 8 (4): 493-505 [Persian].

Leibundgut H. 1933. Europaische Urwaelder. Hauptverlag, Bern. [Germany]

Marvie-Mohadjer MR, Zobeiri M, Etemad V, Jour-Gholami M. 2009. Performing the single selection method at compartment level and necessity for full inventory of tree species. Iranian J Natur Res. 61 (4): 889-908. [Persian]

Mayer P, Tabaku V, Lupke BV. 2004. Die Struktur albanischer Rotbuchen-Urwalder Ableitungen fureine naturnahe Buchenwirtschaft. Forstw Cbl 122: 47-58. [Germany]

Oliver CD, Larson BC. 1996. Forest stands dynamics. Wiley, New York.

Patto M. 2007. A study on natural and disturbed forest stands structure at West Azerbaijan province oak forests. [Thesis]. Gorgan University of Agriculture Sciences and natural resources. p. 84 [Persian]

Pourmajidian MR, Malakshah NE, Fallah A, Parsakhoo A. 2009. Evaluating the shelterwood harvesting system after 25 years in a beech (Fagus orientalis Lipsky) forest in Iran. J For Sci 55 (6): 270278.

Rezaei Sangdehi SMM, Moslemi SM, Tafazoli M. 2017. Comparing the forest quantitative and qualitative characteristics following a period of forestry plan implementation (Case study: Watershed 65, Jojadeh zone of Farim Company, Mazandaran Province), Iranian J For Poplar Res 24 (4): 713-723. [Persian]

Sagheb-Talebi Kh, Sajedi T, Pourhashemi M. 2014. Forest of Iran. A treasure from the past, a hope for future. Plant and Vegetation 10: 149.

Sagheb-Talebi Kh, Schütz JPh. 2002. The structure of natural oriental beech (Fagus orientalis) forests in the Caspian region of Iran and the potential for the application of the group selection system. Forestry 75 (4): 465-472.

Sasanifar S, Namiranian M, Zargham N. 2015. Evaluation Variation Trend in Qualitative Measures in Natural Even-Aged Stand in Kheyroud Forest. For Wood Prod 68 (3): 655-665. [Persian]

Sefidi, K, Copenheaver CA, Kakavand M, Behjou FK. 2015. Structural Diversity within Mature Forests in Northern Iran: A Case Study from a Relic Population of Persian Ironwood (Parrotia persica CA Meyer). For Sci 61 (2): 258-265.

Sharma M, Amateis RL, Burkhart HE. 2003. Forest stands dynamics and similarity theory. Ecol Model167: 165-180.

Suh MH, Lee DK. 1998. Stand structure and regeneration of Quercus mongolica forest in Korea. For Ecol Manag 106: 27-34.

Webb EL, Sah RN. 2003. Structure and diversity of natural and managed sal (Shorea robusta Gaertn. F) Forest in the Terai of Nepal. For Ecol Manag 76: 337-353.

Zobeiri M. Forest Biometry. 2008. Tehran University Press, Tehran, Iran. [Persian] 